University of Nebraska - Lincoln

DigitalCommons@University of Nebraska - Lincoln

Faculty Publications from the Harold W. Manter Laboratory of Parasitology

2005

Presentation of the 2005 ASP Distinguished Service Award to Ralph Lichtenfels

Robin M. Overstreet

Gulf Coast Research Laboratory, robin.overstreet@usm.edu

Follow this and additional works at: https://digitalcommons.unl.edu/parasitologyfacpubs

Part of the Parasitology Commons

Overstreet, Robin M., "Presentation of the 2005 ASP Distinguished Service Award to Ralph Lichtenfels" (2005). Faculty Publications from the Harold W. Manter Laboratory of Parasitology. 422.

https://digitalcommons.unl.edu/parasitologyfacpubs/422

This Article is brought to you for free and open access by the Parasitology, Harold W. Manter Laboratory of at DigitalCommons@University of Nebraska - Lincoln. It has been accepted for inclusion in Faculty Publications from the Harold W. Manter Laboratory of Parasitology by an authorized administrator of DigitalCommons@University of Nebraska - Lincoln. 


\title{
PRESENTATION OF THE 2005 ASP DISTINGUISHED SERVICE AWARD TO RALPH LICHTENFELS
}

\author{
Robin M. Overstreet \\ Chair, Distinguished Service Award and Extramural Awards Committee, Department of Coastal Sciences, The University of Southern \\ Mississippi, P.O. Box 7000, Ocean Springs, Mississippi 39566.
}

Even though data from the National Oceanic and Atmospheric Administration's National Weather Service suggested Hurricane Dennis would strike Mobile, Alabama, and the Society's annual meeting head-on, the ASP records and recollections clearly showed without question that Dr. Ralph Lichtenfels, retired in 2004 from the U.S. Department of Agriculture's National Parasite Collection, Animal Parasitic Diseases Laboratory, in Beltsville, Maryland, deserves the ASP Distinguished Service Award. The award committee, composed of Gerardo Perez Ponce de Leon, Gene Foor, Bruce Conn, and me, evaluated and selected the nomination of Ralph by K. Darwin Murrell, with support from Eric P. Hoberg and R. C. (Tammi) Krecek. We are pleased and privileged that Council has approved our selection of Ralph for the 2005 Distinguished Service Award.

As a high-achieving member of ASP since 1964, Ralph Lichtenfels surpassed all the expected criteria by (1) maintaining continuous membership and regular attendance at annual meetings, (2) participating on numerous committees such as the Committee on Nomenclature and Terminology, the Committee on Standard Methods in Food Parasitology, Translation Committee, the Committee on Priorities, Nominating Committee, the Committee on Special Awards, the Representative to the Biological Survey of the United States, the Editorial Board of the Journal of Parasitology, and Council Member at Large, and (3) exhibiting exceptional leadership as President in 1994 by initiating several important programs and policies as well as serving as (a) both Secretary-Treasurer and President of The Helminthological Society of Washington, our oldest regional society, plus Editor of its journal (now named Comparative Parasitology) and (b) in leadership roles in the Federation of Societies for Parasitology, American Association for Zoological Nomenclature, and Association of Systematics Collections. As curator of the U.S. National Parasite Collection (USNPC) from 1973 to 1999 , Ralph served the Collection, the Society, and the parasitology community by promoting collections, establishing standards, instituting Web-based record keeping, publishing numerous important papers, identifying parasites, and serving as our ambassador to parasitologists of the world.

Ralph has used diagnostics, identifications, and keys to promote parasitology and provide the essential systematics information necessary to protect the health of animals and ultimately our food supply. As Curator, he annually identified 700-1,000 submitted parasites, accessioned more than 1,000 specimens, and loaned out over 500 specimens. In 1998, he established the USNPC as the first parasite collection, truly an international treasure, online. Society committee work with Mary Lou Pritchard led to the 1982 publication of A Guide to Parasite Collections of the World. His personal interest was nematodes of equids and ruminants, and, as examples of his important research, he pioneered the revolutionary development of surface cuticular ridges, also known as synlophe patterns, to differentiate trichostrongyles of livestock, produced illustrated keys for strongyles of horses necessary to bring order out of chaos, provided a strong conceptual framework for the systematics and identification of strongyles and hookworms with his CAB keys, and used his research and leadership skills to allow proper understanding and treatment of the many parasitized farmed animals. Others know him for efforts, including those involved with his nearly 150 peer-reviewed publications, directed toward evaluating nematodes and other parasites of their favorite hosts, including people.

Most parasitologists know but do not necessarily appreciate that accurate identifications of parasitic species are critical to understanding host and parasite biology. These identifications in turn allow the resulting information to be used accurately for assessments, treatments, and future research. Without such identifications, decisions regarding public health, animal health, host or parasite ecology, host or parasite biology, biodiversity, treatment, control, management, and regulations can be misleading, incorrect, and even disastrous to the host, ecosystem, or society. Ralph not only understood this, but he directed his research, service, and attention to promoting this critical aspect of parasitology to parasitologists, biologists, administrators, and the general public.

Ralph's qualifications as ASP's ambassador are multiple, and they reinforce the high standards we have set for the award. A quick glance at the acknowledgments of most critical taxonomic articles published over the past 3 decades provides the evidence for gratitude to Ralph for loan of necessary specimens for comparative purposes or other assistance. He served as parasitology's representative and spokesperson in the museum community. Most of his activities were in North America, but he also represented us well on an international basis. In his quiet, unobtrusive manner in meetings of The Society and other groups, Ralph also provided historical memory for events, procedures, methods, and regulations and thereby prevented the creation of problems before they developed. This talent has served the Society since 1967 when he was hired by the USDA in Beltsville and 1968 when he received his doctorate from the University of Maryland. It continued to help him as he served as a Visiting Professor at the University of Melbourne and the University of Glasgow in the late 1990s. We consider ourselves honored, privileged, and thankful to be able to recognize Ralph Lichtenfels, as he has recognition by the American Association of Veterinary Parasitologists and the Friends of the Beltsville Agricultural Research Center for similar honors, with our own Distinguished Service Award. Congratulations, Ralph! 